\title{
KUALITAS PENGUNGKAPAN CSR PADA PERUSAHAAN LQ45 DAN FAKTOR YANG MEMPENGARUHINYA
}

\author{
Badingatus Solikhah \\ Universitas Negeri Semarang \\ badingatusbety@mail.unnes.ac.id \\ Adistya Kuswoyo \\ Universitas Negeri Semarang \\ adistyakuswoy051@gmail.com
}

\begin{abstract}
The purpose of this study is to examine the effect of board commissioners meeting frequency, board directors gender diversity, institutional ownership, managerial ownership, industrial sensitivity, and slack resources on CSR disclosure. The population of this study is LQ45 companies listed on the Indonesia Stock Exchange. The sample selection used purposive sampling method, thus obtained 77 unit of analysis. This study used multiple regression analysis. The results showed that frequency of board commissioners meeting and indsutry sensitivity has positive significant effect on CSR disclosure. Meanwhile, boar director gender diversity, innstitutional ownership, managerial ownership, and slack resources do not affect the CSR disclosure.
\end{abstract}

Keyword: Board Meeting Frequency; Gender Diversity; Ownership Structure; Slack Resources; CSR Disclosure

\section{PENDAHULUAN}

Pertumbuhan bisnis yang semakin berkembang pesat menciptakan persaingan antar perusahaan menjadi lebih ketat (Handrian \& Fahmi, 2015). Anggapan mengenai tujuan kegiatan operasional perusahaan yang hanya mencari laba atau keuntungan sudah tidak relevan. Seiring berjalannya waktu perusahaan mulai menyadari akan kepentingannya dalam melakukan tanggung jawab sosial yang mendorong perubahan orientasi perusahaan kepada meningkatkan citra maupun menambah nilai kompetitif perusahaan sehingga perusahaan tetap bisa hidup dan menjaga keberlanjutan (sustainability) bisnis. Salah satu cara yang dilakukan oleh perusahaan untuk mengakomodasi meningkatnya kesadaran akan keberlanjutan adalah dengan melakukan praktik pelaporan Corporate Social
Responsibility (yang selanjutnya disingkat CSR) (Bouten \& Everaert, 2015). Tanggung jawab sosial perusahaan atau yang lebih dikenali sebagai CSR merupakan aktivitas tanggung jawab perusahaan terhadap para stakeholder dengan cara memberi perhatian terhadap aspek sosial dan aspek lingkungan (Nugroho \& Yulianto, 2015).

CSR di Indonesia semakin menguat sejak pemerintah mengesahkan UU No. 40 Tahun 2007 tentang Perseroan Terbatas dan Peratutan Pemerintah No. 47 Tahun 2012 tentang Tangggung Jawab Sosial dan Lingkungan Perseroan Terbatas serta undang-ungang dan regulasi-regulasi lain yang berkaitan dengan CSR. Namun, masih terdapat kasus-kasus yang menyebabkan konflik permasalahan CSR antara lain pencemaran lingkungan akibat aktivitas tambang yang buruk oleh perusahaan 
tambang di Kabupaten Malinau (kaltim.tribunnews, 2017) dan pencemaran sungai akibat tanggul limbah yang jebol oleh pabrik kelapa sawit PT Eluan Mahkota (Riaunews, 2017). Banyaknya kasus lain yang terungkap seperti hal yang terjadi pada PT Freeport di Jayapura, PT Exxon Mobil di Lhokseumawe, PT Newmont di Minahasa Raya dan lain sebagainya menguatkan lagi pertanyaan mengenai aktivitas CSR yang dilakukan perusahaan dalam menjaga kelangsungan bisnisnya. Selain itu, inkonsistensi yang terdapat pada pelaporan data CSR di Indonesia menunjukkan bahwa masih banyak perusahaan yang belum secara konsisten memberikan perhatian yang baik terhadap pelapotan aktivitas sosialnya.

Penelitian terdahulu menggunakan variabel-variabel yang diprediksi mampu mempengaruhi pengungkapan CSR seperti frekuensi rapat dewan komisaris (Charles \& Chariri, 2012; Dienes dan Velte, 2015; Haribowo, 2015; Naseem et al., 2017), diversitas gender (Margaretha dan Isnaini, 2014; Othman et al., 2017; Anggraeni dan Djakman, 2017; Al-Baab dan Yunia, 2017), kepemilikan institusional (Sari et al., 2013; Nussy, 2013; Purwanty et al., 2017; Jurnali et al., 2017), kepemilikan manajerial (Nussy, 2013; Purwanty et al., 2017; Jurnali et al., 2017; Anita, 2017), sensitivitas industri (Razak, 2015; Solikhah, 2016; Barusman dan Lindrianasari, 2016; Othman et al., 2017), dan slack resources (Anggraeni dan Djakman, 2017; Julia, 2017; Sayekti, 2017; Yusuf et al., 2017).

Adanya hasil yang tidak konsisten di antara beberapa penelitian menjadikan CSR menjadi hal yang menarik untuk diteliti kembali. Penelitian ini dilakukan dengan merujuk pada penelitian-penelitian sebelumnya mengenai CSR. Peneliti menghadirkan slack resources sebagai variabel tambahan dalam penelitian dikarenakan variabel ini masih jarang untuk diteliti. Hasil ini menunjukkan masih adanya ketidakkonsistenan pada hasil penelitian Julia (2017) yang menyatakan bahwa slack resources tidak berpengaruh terhadap pengungkapan CSR sementara hasil penelitian Sayekti (2017) dan Anggraini \& Djakman (2017) menunjukkan adanya pengaruh slack resources terhadap pengungkapan CSR. Sehingga, tujuan penelitian ini adalah untuk mengetahui pengaruh frekuensi rapat dewan komisaris, diversitas gender dewan direksi, kepemilikan institusional, kepemilikan manajerial, sensitivitas industri dan slack resources terhadap pengungkapan CSR pada perusahaan yang terindeks LQ45 periode 2013-2016.

Terdapat empat teori yang melandasi penelitian ini. Teori legitimasi menyatakan bahwa organisasi yang beroperasi di masyarakat harus melakukan tindakan yang diinginkan oleh masyarakat sebagai balasan atas diterimanya tujuan dan untuk kelangsungan hidup perusahaan (Guthrie dan Parker, 1989). Teori stakeholder oleh Freeman dan Reed (1983) menyatakan bahwa terdapat keterkaitan antara perusahaan dengan seluruh elemen kebijakannya dan stakeholder sehingga dapat mempengaruhi pencapaian tujuan organisasi. Selain itu, Jensen dan Meckling (1976) dalam teori agensinya menyatakan bahwa hubungan keagenan merupakan kontrak antara principal dan agent dalam melakukan beberapa tindakan pelayanan atas nama mereka yang melibatkan pengambilan keputusan keagenan. Sedangkan, terdapat teori resource based yang menyatakan bahwa sumber daya yang dimiliki oleh organisasi dapat beradaptasi secara sukses baik dari tekanan internal maupun eksternal untuk melakukan 
perubahan kebijakan perusahaan (Bourgeois, 1981).

Selain teori legitimasi dan stakeholder, penelitian ini juga menggunakan teori agensi yang menyatakan bahwa terdapat dua sisi kepentingan yang berbeda yaitu pihak agent (manajemen) dan pihak principal (pemegang saham). Winarsih dan Solikhah (2015) menyatakan bahwa untuk memberikan bentuk pertanggungjawaban perusahaan terhadap dua kepentingan tersebut adalah dengan menggunakan sistem tata kelola perusahaan (corporate governance) dimana didalamnya terdapat Corporate Social Responsibility sebagai bentuk kepedulian perusahaan terhadap lingkungan.

\section{TINJAUAN PUSTAKA DAN PENGEMBANGAN HIPOTESIS}

Rapat dewan adalah suatu proses yang dilakukan baik oleh dewan komisaris maupun dewan direksi dalam waktu satu tahun sebagai bagian dari tata kelola perusahaan. Laksmana (2008) dan Rizki et al. (2014) menyatakan bahwa jumlah pertemuan yang teratur memberi mereka kesempatan untuk berbagi lebih banyak informasi dan meningkatkan pengambilan keputusan yang pada akhirnya akan meningkatkan nilai perusahaan. Dalam rangka menjalankan tugasnya, Dewan Komisaris mengadakan rapat-rapat rutin untuk mengevaluasi kebijakan-kebijakan yang diambil oleh dewan direksi dan implementasinya (Charles dan Chariri, 2012). Rapat dewan bisa dijelaskan dengan teori stakeholder dimana rapat yang dilakukan dapat mengurangi perilaku oportunis manajemen sekaligus meningkatkan nilai perusahaan. Naseem $e t$ al. (2017) dan Rizki et al. (2014) menemukan bahwa rapat dewan mempunyai hubungan yang positif terhadap pengungkapan CSR.

\section{$H_{1}$ : Frekuensi rapat dewan komisaris berpengaruh positif signifikan terhadap pengungkapan CSR}

Dewan direksi di sebuah perusahaan juga hadir bersama dengan adanya presensi direktur wanita. Machold et al. (2008) dalam penelitiannya mengaitkan tata kelola perusahan dengan perspektif wanita di mana sosok wanita memiliki pandangan yang berbeda dalam mengomunikasikan pendapat mereka sehingga akan memengaruhi kebijakan yang akan ditetapkan. Ketika wanita berada di dalam dewan, secara tidak langsung akan meningkatkan keunikan, juga akan memunculkan pendapat yang berbeda, perspektif, pengalaman, dan gaya kerja dalam kaitannya dengan direksi laki-laki (Giannarakis, 2014). Penelitian yang dilakukan oleh Ibrahim dan Hanefah (2016) di Jordan menemukan bahwa proporsi dewan direksi berpengaruh positif signifikan terhadap pengungkapan CSR.

$\mathrm{H}_{2}$ : Diversitas gender dewan direksi berpengaruh positif signifikan terhadap pengungkapan CSR

Kepemilikan institusional adalah kepemilikan saham perusahaan oleh institusi (badan), biasanya berbentuk entitas seperti perbankan, asuransi, dana pensiun, reksa dana, dan institusi lain. Pemilik institusional dianggap memiliki hak suara yang lebih besar dan kemungkinan asimetri informasi akan lebih besar daripada pemegang saham lainnya. Mereka juga lebih mungkin terlibat aktif dalam manajemen lingkungan perusahaan praktek dari pemegang saham lainnya (Diantimala dan Amril, 2018). Penelitian Sari et al. (2013), (Sunarsih dan Nurhikmah, 2017) 
dan Nugroho dan Yulianto (2015) menunjukkan bahwa kepemilikan institusional berpengaruh terhadap pengungkapan CSR.

\section{$\mathrm{H}_{3}$ : Kepemilikan institusional berpengaruh positif signifikan terhadap pengungkapan CSR}

Kepemilikan manajerial adalah kondisi yang menunjukkan bahwa manajer memiliki saham dalam perusahaan atau manajer tersebut sekaligus sebagai pemegang saham perusahaan. Berdasarkan teori keagenan, hubungan antara manajemen dengan pemegang saham rawan terjadi masalah keagenan. Menurut Mursalim (2007), kepemilikan institusional dapat dijadikan sebagai upaya untuk mengurangi masalah keagenan dengan meningkatkan proses monitoring. Penelitian Karima (2014) dan Purwanty et al. (2017) menunjukkan bahwa kepemilikan manajerial berpengaruh signifikan terhadap pengungkapan CSR.

\section{$H_{4}$ : Kepemilikan manajerial berpengaruh positif signifikan terhadap pengungkapan CSR}

Tipe industri atau sensitivitas industri adalah karakteristik yang dimiliki oleh perusahaan yang berkaitan dengan bidang usaha, risiko usaha, karyawan yang dimiliki dan lingkungan perusahaan. Perusahaan-perusahaan high-profile pada umumnya merupakan perusahaan yang memperoleh sorotan dari masyarakat berbanding perusahaan low-profile karena aktivitas operasinya memliki potensi untuk bersinggungan dengan kepentingan luas. Penelitian dari (Purwanto, 2011) dan Susilawati et al. (2014) sama-sama menyatakan bahwa jenis industri berpengaruh terhadap pengungkapan pertanggungjawaban sosial. Solikhah (2016) dalam penelitiannya menemukan bukti empiris bahwa sensitivitas industri berpengaruh positif terhadap pengungkapan tanggung jawab sosial.

$\mathrm{H}_{5}$ : Sensitivitas industri berpengaruh positif signifikan terhadap pengungkapan CSR

Dalam upaya kegiatan aktivitas CSR, perusahaan setidaknya harus mengalokasikan sejumlah dana dan sumber daya tertentu agar kegiatan CSR dapat terlaksana dengan baik. Ketika segala aktivitas tersebut telah terlaksana, maka perusahaan memiliki data dan informasi yang cukup untuk nantinya disajikan dalam bentuk laporan pengungkapan CSR (Anggraeni dan Djakman, 2017). (Sayekti, 2017) mengatakan bahwa slack resources yang dimiliki perusahaan akan memengaruhi kebijakan perusahaan dalam menentukan seberapa luas keterlibatan mereka dalam aktivitas CSR. Perusahaan yang memiliki slack resources yang tinggi diharapkan menggunakan sumber dana dan daya yang dimiliki oleh perusahaan sehingga akan dapat melaksanakan pelaporan investasi CSR yang lebih tinggi lagi.

$\mathrm{H}_{6}$ : Slack resources berpengaruh positif signifikan terhadap pengungkapan CSR 
Model penelitian ini dapat digambarkan dalam kerangka pemikiran sebagai berikut:

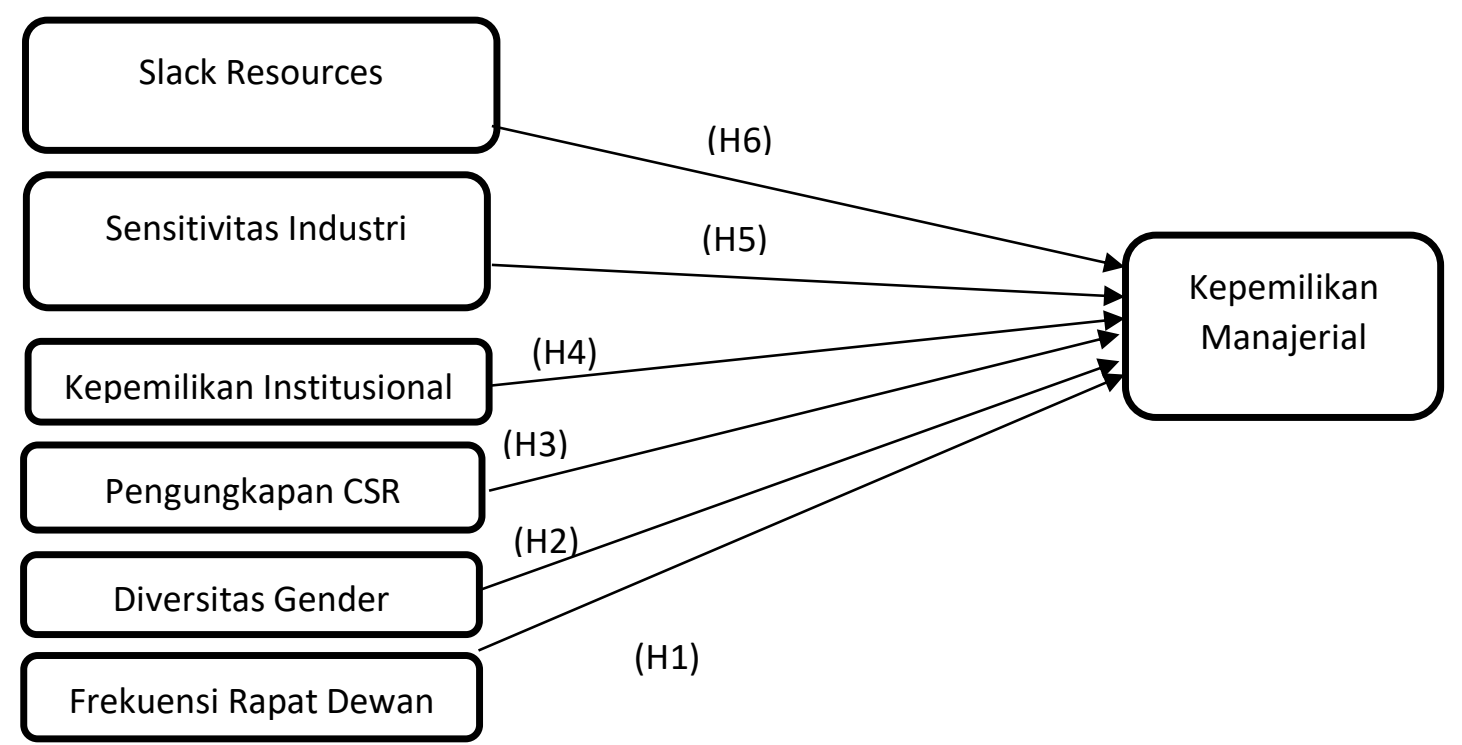

\section{Gambar 1. Hasil Model Penelitian}

\section{METODE PENELITIAN}

Jenis penelitian ini adalah penelitian kuantitatif dengan menggunakan data sekunder. Populasi dalam penelitian ini adalah perusahaan-perusahaan LQ45 selama tahun 2013-2016 yang terdaftar di Bursa Efek Indonesia (BEI). Metode dalam penelitian ini menggunakan teknik purposive sampling sehingga menghasilkan 77 unit analisis. Metode analisis yang digunakan adalah analisis statistik deskriptif dan analisis regresi berganda. Kriteria pemilihan sampel dapat dilihat pada tabel 1 berikut di bawah ini.

Tabel 1

\section{Kriteria Pemilihan Sampel}

\begin{tabular}{clc}
\hline No. & \multicolumn{1}{c}{ Kriteria } & Jumlah \\
\hline 1. & $\begin{array}{l}\text { Jumlah perusahaan LQ45 yang terdaftar di Bursa Efek Indonesia } \\
\text { secara konsisten dan berturut-turut selama tahun 2013-2016 }\end{array}$ & 26 \\
\hline $\begin{array}{l}\text { Jumlah perusahaan LQ45 yang menggunakan mata uang selain } \\
\text { Rupiah }\end{array}$ & 2 \\
\hline Jumlah perusahaan yang menjadi sampel penelitian & 24 \\
\hline Tahun Penelitian & 4 \\
\hline Jumlah data penelitian selama tahun 2013-2016 (24x4) & 96 \\
\hline Data outlier selama tahun penelitian & 19 \\
\hline Jumlah unit analisis & 77 \\
\hline
\end{tabular}

Penelitian ini menggunakan tujuh variabel penelitian yang terdiri dari satu variabel dependen dan enam variabel independen. Variabel dependen pada penelitian ini adalah pengungkapan Corporate Social Responsibility (CSR). 
Pengungkapan CSR adalah pengungkapan tanggung jawab terhadap segala aspek operasional perusahaan yang mencakup aspek ekonomi, sosial, dan lingkungan. Pengukuran indeks pengungkapan CSR dilakukan dengan menganalisis annual report dan atau sustainability report masing-masing perusahaan dengan menggunakan GRI versi 4.0.

Tabel 2

Definisi Operasional dan Pengukuran Variabel Penelitian

\begin{tabular}{|c|c|c|c|}
\hline No & Definisi Variabel & Pengukuran & Literatur \\
\hline \multicolumn{4}{|c|}{ Dependen } \\
\hline 1. & $\begin{array}{l}\text { Pengungkapan CSR merupakan } \\
\text { pengungkapan yang dilakukan oleh } \\
\text { perusahaan atas kebijakan atau tindakan } \\
\text { yang menunjukkan identitas perusahaan } \\
\text { sebagai entitas yang peduli terhadap } \\
\text { masalah sosial. }\end{array}$ & $\begin{array}{l}\text { Skor luas } \\
\text { pengungkapan CSR } \\
\text { perusahaan dibagi } \\
\text { skor maksimum luas } \\
\text { pengungkapan CSR } \\
\text { (91 item) }\end{array}$ & $\begin{array}{l}\text { Nurkhin, 2010; } \\
\text { Nugroho dan } \\
\text { Yulianto, 2015; } \\
\text { Krisna dan Subianto } \\
\text { (2016) }\end{array}$ \\
\hline & & $\mathrm{CSRD}_{\mathrm{it}}=\frac{\sum \mathrm{Xij}}{\mathrm{nj}}$ & \\
\hline
\end{tabular}

\section{Independen}

2. Frekuensi Rapat Dewan merupakan suatu proses yang ditempuh oleh dewan direksi dan dewan komisaris dalam pengambilan keputusan dan pengawasan mengenai kebijakan perusahaan.

\section{Diversitas Gender Dewan Direksi} merupakan komposisi wanita yang terdapat dalam suatu dewan direksi.

$\begin{array}{ll}\text { Jumlah rapat anggota } & \text { Dienes dan Velte } \\ \text { dewan komisaris } & \text { (2015); Naseem } \text { et } \\ \text { dalam satu tahun } & \text { al. } \text { (2017) }\end{array}$

al. (2017)

$\begin{array}{ll}\text { Rasio dewan direksi } & \text { Anggraeni dan } \\ \text { wanita dibagi jumlah } & \text { Djakman (2017) }\end{array}$

dewan direksi.

Dewan Direksi Wanita

Dewan Direksi

\begin{tabular}{llll}
\hline 4. & Kepemilikan Institusional merupakan & Jumlah saham yang & Sari et al. \\
kepemilikan saham perusahaan yang & dimiliki institusional & (2013) \\
dimiliki oleh institusi atau lemaba & dibagi total & \\
seperti perusahaan asuransi, bank, & $\begin{array}{l}\text { keseluruhan saham. } \\
\text { perusahaan investasi, dan kepemilikan } \\
\text { institusi lainnya. }\end{array}$ & $\begin{array}{l}\text { Iumlah saham yang dimiliki } \\
\text { oleh institusional }\end{array}$ & Total Saham Beredar
\end{tabular}

5. Kepemilikan Manajerial adalah situasi

Jumlah saham yang

Robiah dan Erawati dimana manajer memiliki saham perusahaan atau dengan kata lain manajer tersebut sekaligus sebagai pemegang saham perusahaan. dimiliki manajemen

dibagi total

keseluruhan saham. 


\begin{tabular}{|c|c|c|c|}
\hline No & Definisi Variabel & Pengukuran & Literatur \\
\hline & & $\begin{array}{c}\begin{array}{c}\text { umlah saham yang dimiliki } \\
\text { oleh manajerial }\end{array} \\
\text { Total Saham Beredar }\end{array}$ & \\
\hline 6. & $\begin{array}{l}\text { Sensitivitas Industri merupakan } \\
\text { pengaruh aktivitas industri yang } \\
\text { bersinggungan langsung dengan } \\
\text { lingkungan. }\end{array}$ & $\begin{array}{l}\text { Diukur dengan dummy } \\
\text { variable, } 1 \text { dan } 0 . \\
\text { Bernilai } 1 \text { jika } \\
\text { perusahaan termasuk } \\
\text { ke dalam industri } \\
\text { high-profile, dan } 0 \\
\text { jika low-profile }\end{array}$ & $\begin{array}{l}\text { Sembiring (2005); } \\
\text { Solikhah (2016), } \\
\text { Anggraeni dan } \\
\text { Djakman (2017) }\end{array}$ \\
\hline 7. & $\begin{array}{l}\text { Slack Resources adalah ketersediaan } \\
\text { sumber daya berlebih yang tidak atau } \\
\text { belum digunakan untuk tujuan apapun, } \\
\text { yang dapat digunakan perusahaan untuk } \\
\text { beradaptasi dengan perubahan kondisi } \\
\text { tekanan internal dan eksternal. }\end{array}$ & $\begin{array}{l}\text { Nilai kas dan setara } \\
\text { kas di trasformasi } \\
\text { menjadi logaritma } \\
\text { natural kas dan setara } \\
\text { kas. }\end{array}$ & $\begin{array}{l}\text { Burgeois, 1981, } \\
\text { Arora dan } \\
\text { Dharwadhakar, } \\
\text { 2011; Harrison dan } \\
\text { Coombs, 2012; } \\
\text { Anggraeni dan } \\
\text { Djakman (2017) }\end{array}$ \\
\hline
\end{tabular}

HASIL DAN PEMBAHASAN

Tabel 3

Descriptive Statistics

\begin{tabular}{lrrrrr}
\hline & N & Minimum & Maximum & \multicolumn{1}{c}{ Mean } & $\begin{array}{c}\text { Std. } \\
\text { Deviation }\end{array}$ \\
\hline FREQ & 77 &, 00 & 57,00 & 15,3896 & 15,56071 \\
\hline GEND & 77 &, 00 &, 63 &, 1432 &, 14992 \\
\hline INST & 77 & 7,07 & 85,00 & 50,5506 & 17,63470 \\
\hline MANJ & 77 &, 00 &, 92 &, 1154 &, 24446 \\
\hline SENSI & 77 &, 00 & 1,00 &, 6364 &, 48420 \\
\hline SLACK & 77 & 12,83 & 19,06 & 15,5613 & 1,65885 \\
\hline CSR & 77 &, 08 &, 42 &, 1798 &, 09263 \\
\hline
\end{tabular}

Berdasarkan table 3 di atas dapat diketahui bahwa dari 77 unit analisis yang diteliti, nilai terendah dari variabel . Hasil analisis deskriptif menunjukkan bahwa nilai rata-rata untuk variabel pengungkapan CSR adalah sebesar 17,9\% yaitu hanya sebesar 16 item pengungkapan dari total maksimal 91 kriteria. Hal tersebut mengindikasikan bahwa tingkat pengungkapan CSR pada perusahaan LQ45 masih dalam kategori rendah. Nilai terendah yaitu sebesar 7,69\% dimiliki oleh PT. Alam Sutera Realty Tbk. (ASRI), PT. Charoen Pokphand Indonesia Tbk. (CPIN), dan PT. Media Nusantara Citra Tbk. (MNCN) sebesar 7 item pengungkapan. Sedangkan, nilai pengungkapan tertinggi sebesar $41,75 \%$ oleh PT. Semen Indonesia 
(Persero) Tbk. (SMGR) sebesar 38 item pengungkapan.

Nilai rata-rata variabel frekuensi rapat dewan komisaris adalah sebesar 15,389 menandakan bahwa dewan komisaris sudah melaksanakan rapat sesuai peraturan dari Otoritas Jasa Keuangan (POJK) Pasal 31 No. 33 Tahun 2014. Nilai rata-rata variabel diversitas gender adalah sebesar 0,143 dan 50,550 menunjukkan bahwa diversitas gender mempunyai nilai yang rendah dan kepemilikan institusional memiliki nilai yang sedang. Variabel kepemilikan manajerial memiliki nilai ratarata yang sangat rendah yaitu sebesar 0,115 karena kepemilikan manajerial kurang dari 5\% dari saham perusahaan. Variabel sensitivitas industri dinyatakan sebagai industri high profile dengan nilai rata-rata sebesar 0,636. Sedangkan, slack resources mempunyai nilai rata-rata sebesar 15,561 dengan kategori sedang.

Uji normalitas dapat dilakukan dengan menggunakan uji KolmogorovSmirnov, dilihat dari variabel pengganggu atau residual memiliki nilai asymptotic significant sebesar 2.000 (lebih besar dari
0,05) yang mengindikasikan bahwa data tersebut terdistribusi secara normal. Hasil multikolinieritas korelasi antar variabel independen menunjukkan bahwa nilai VIF $<10$ dan nilai tolerance $>0,10$. Hal ini menunjukkan bahwa model regresi pada penelitian ini tidak terjadi multikolinearitas. Hasil uji heteroskedastisitas menunjukkan bahwa masing-masing variabel independen memiliki nilai Sig. > 0,05. Jadi dapat disimpulkan bahwa model regresi tidak mengandung heteroskedastisitas. Secara umum model regresi telah memenuhi persyaratan uju asumsi klasik.

Uji hipotesis menunjukkan nilai adjusted $R$ square sebesar 0,477 artinya bahwa $47,7 \%$ variasi dari pengungkapan CSR dapat dijelaskan oleh frekuensi rapat dewan komisaris, diversitas gender dewan direksi, kepemilikan institusional, kepemilikan manajerial, sensitivitas industri, dan slack resources. Sisanya sebesar 52,3\% dijelaskan oleh variabel lain diluar model penelitian ini. Hasil pengujian hipotesis dapat dilihat pada Tabel 2 dengan nilai $\alpha$ sebesar 0,05 .

Tabel 4

Hasil Uji Hipotesis

\begin{tabular}{llccc}
\hline \multicolumn{1}{c}{ Hipotesis } & B & Sig & Hasil \\
\hline $\mathrm{H}_{1}$ & $\begin{array}{l}\text { Frekuensi rapat dewan komisaris berpengaruh } \\
\text { positif signifikan terhadap pengungkapan CSR }\end{array}$ & 0,002 & 0,004 & Diterima \\
\hline $\mathrm{H}_{2}$ & $\begin{array}{l}\text { Diversitas gender dewan direksi berpengaruh } \\
\text { negatif signifikan terhadap pengungkapan CSR }\end{array}$ & $-0,276$ & 0,000 & Ditolak \\
\hline $\mathrm{H}_{3}$ & $\begin{array}{l}\text { Kepemilikan institusional tidak berpengaruh } \\
\text { signifikan terhadap terhadap pengungkapan CSR }\end{array}$ & 0,000 & 0,697 & Ditolak \\
\hline $\mathrm{H}_{4}$ & $\begin{array}{l}\text { Kepemilikan manajerial berpengaruh negatif } \\
\text { signifikan terhadap terhadap pengungkapan CSR }\end{array}$ & $-0,087$ & 0,014 & Ditolak \\
\hline $\mathrm{H}_{5}$ & $\begin{array}{l}\text { Sensitivitas industriberpengaruh positif signifikan } \\
\text { terhadap terhadap fpengungkapan CSR }\end{array}$ & 0,051 & 0,015 & Diterima \\
\hline $\mathrm{H}_{6}$ & $\begin{array}{l}\text { Slack resources tidak berpengaruh terhadap } \\
\text { terhadap pengungkapan CSR }\end{array}$ & $-0,002$ & 0,741 & Ditolak \\
\hline
\end{tabular}




\section{Pengaruh Frekuensi Rapat Dewan Komisaris terhadap Pengungkapan CSR}

Hasil analisis menunjukkan bahwa frekuensi rapat dewan komisaris berpengaruh positif dan signifikan terhadap pengungkapan CSR diterima. Artinya perusahaan yang memiliki frekuensi rapat dewan komisaris yang lebih intensif memiliki kecenderungan pengungkapan CSR yang lebih luas. Hal tersebut diduga bahwa dalam pelaksanaan dewan komisaris diantaranya juga menyoroti terkait dengan praktik maupun pengungkapan CSR yang dilakukan perusahaan. Hasil tersebut sejalan dengan teori stakeholder, dimana frekuensi rapat yang dilakukan oleh dewan komisaris dapat meningkatkan tanggung jawab, dan mengawasi manajemen agar berhati-hati dalam bertindak dan mengambil keputusan, serta mengurangi perilaku oportunis dari manajemen. Tanggung jawab dewan komisaris yaitu untuk memastikan bahwa pelaksanaan operasional perusahaan oleh manajemen dijalankan sesuai peraturan perundangundangan termasuk peraturan pengungkapan CSR. Hasil penelitian ini sesuai dengan penelitian yang dilakukan oleh Rizki et al (2014) yang menunjukkan bahwa frekuensi rapat dewan komisaris berpengaruh positif terhadap pengungkapan CSR. Rizki et al. (2014) mengungkapkan bahwa semakin banyak jumlah pertemuan dewan komisaris akan memberikan lebih banyak waktu untuk membahas pelaksanaan corporate governance termasuk pengungkapan CSR. Rapat dewan komisaris merupakan salah satu ruang yang insentif untuk mengarahkan, memantau, dan mengevaluasi pelaksanaan kebijakan strategis. Rapat dewan komisaris yang diadakan mampu memberikan nilai tambah bagi perusahaan, termasuk meningkatkan pengungkapan CSR.

\section{Pengaruh Diversitas Gender Dewan Direksi terhadap Pengungkapan CSR}

Hasil analisis menunjukkan bahwa diversitas gender dewan direksi berpengaruh negatif dan signifikan terhadap pengungkapan CSR, sehingga hipotesis ditolak. Hal ini menunjukkan bahwa semakin tinggi diversitas gender yang terdapat dalam dewan direksi maka pengungkapan CSR akan cenderung lebih rendah. Hasil ini tidak selaras dengan teori resource based yang mendukung adanya pengaruh positif antara diversitas gender dan pengungkapan CSR. Hal tersebut terjadi diduga karena adanya sumber daya manusia yang beragam dari segi gender ternyata kurang mampu berpengaruh dalam memperoleh hasil yang signifikan. Hasil ini juga tidak mendukung teori stakeholder di mana jumlah wanita yang sedikit dalam struktur direksi perusahaan kurang bisa memberikan perhatian yang baik kepada para stakeholder dan mendorong perilaku perusahaan yang lebih baik pada masalahmasalah terkait sosial dan lingkungan. Hasil tersebut sejalan dengan penelitian yang dilakukan oleh Anggraeni dan Djakman (2017), Handajani et al. (2014), serta Muttakin et al. (2015) yang menyatakan bahwa diversitas gender tidak signifikan terhadap pengungkapan CSR. Handajani et al. (2014) menjelaskan bahwa jumlah yang sedikit dari komposisi gender dalam dewan direksi tidak dapat mendorong dan meningkatkan perilaku etis perusahaan, termasuk formulasi strategi CSR dan kebijakan perusahaan.

\section{Pengaruh Kepemilikan Institusional terhadap Pengungkapan CSR}


Hasil analisis menunjukkan bahwa tidak terdapat pengaruh antara kepemilikan institusional dan pengungkapan CSR. Hasil penelitian ini mematahkan teori agensi, di mana perusahaan yang memiliki kepemilikan institusional yang tinggi tidak terlihat berusaha untuk mengurangi biaya keagenan melalui tanggung jawab sosial. Kendati terdapat investor institusional, kinerja pengungkapan tanggung jawab sosial tidak berubah karena bisa jadi tujuan kepemilikan hanya untuk investasi jangka pendek (Krisna dan Suhardianto, 2016). Analisis deskreptif terhadap variable kepemilikan institusi menunjukkan angka rata-rata sebesar 50,55\%, dengan demikian tingkat kepemilikan institusional yang dimiliki sebagian besar perusahaan termasuk dalam kategori tinggi. Walaupun hasil analisis deskriptif menunjukkan tingkat kepemilikan institusional yang tinggi, akan tetapi hasil penelitian menunjukkan bahwa tingginya kepemilikan institusional yang dimiliki perusahaan tidak mempengaruhi luas pengungkapan CSR. Hasil penelitian ini sejalan dengan penelitian yang dilakukan oleh Utami dan Rahmawati (2010) dan Krisna dan Suhardianto (2016) yang menunjukkan hasil bahwa kepemilikan institusional tidak berpengaruh terhadap pengungkapan CSR.

\section{Pengaruh Kepemilikan Manajerial terhadap Pengungkapan CSR}

Hasil analisis menunjukkan bahwa kepemilikan manajerial berpengaruh negatif signifikan terhadap pengungkapan CSR. Hasil tersebut membuktikan bahwa penelitian ini tidak sejalan dengan teori agensi dimana manajer dalam perusahaan akan berusaha untuk memaksimalkan kepentingannya sendiri dibandingkan kepentingan perusahaan. Dewi dan Priyadi
(2013) juga menunjukkan hasil yang sama dengan penelitian ini di mana kepemilikan manajerial berpengaruh negatif terhadap pengungkapan CSR. Alasan yang bisa menjelaskan ini dikarenakan kepemilikan manajerial yang sedikit dalam perusahaan mampu menjadikan proses monitoring menjadi lebih baik sehingga informasi yang dimiliki oleh pihak manajemen dapat dilakukan secara menyeluruh kepada stakeholders perusahaan. Selain itu, kepemilikan manajerial yang berjumlah besar juga menjadi kurang efektif karena konflik kepentingan antara manajer dengan pemilik menjadi semakin besar, manajer akan berusaha untuk memaksimalkan kepentingan dirinya sehingga mengesampingkan kepentingan perusahaan. (Dewi dan Priyadi, 2013).

\section{Pengaruh Sensitivitas Industri terhadap} Pengungkapan CSR

Hasil analisis menunjukkan bahwa sensitivitas industri berpengaruh secara positif dan signifikan terhadap pengungkapan CSR. Penelitian ini sesuai dengan teori legitimasi dan teori stakeholders dimana perusahaan dengan dampak besar terhadap lingkungan dan para pemangku kepentingan akan mengungkapkan informasi lingkungan secara lebih luas. Perusahaan high profile dianggap menghasilkan lebih banyak menghasilkan limbah dan kerusakan lingkungan dalam proses dan produksi operasionalnya sehingga pengungkapan CSR yang diungkapkan juga akan semakin banyak. Solikhah (2016) menyatakan bahwa perusahaan dengan high profile cenderung mengekspresikan tanggung jawab sosialnya karena perusahaan dalam kategori ini lebih rentan terhadap pelanggaran yang terkait dengan bisnisnya. Hasil penelitian ini sejalan dengan 
penelitian yang dilakukan oleh Sembiring (2005), Razak (2015) Barusman dan Lindrianasri (2016), dan Solikhah (2016) di mana sensitivitas industri berpengaruh positif signifikan terhadap pengungkapan CSR.

\section{Pengaruh Slack Resources terhadap Pengungkapan CSR}

Hasil analisis menunjukkan bahwa variabel slack resources tidak berpengaruh terhadap pengungkapan CSR. Hasil tersebut tidak sejalan dengan teori resourced based dimana semakin banyak kelonggaran organisasi yang dimiliki oleh perusahaan, semakin kerap penggunaan dana tambahan tersebut untuk kebutuhan operasional dan peningkatan kualitas perusahaan. Walaupun sumber daya tambahan dengan karakteristik diskresioner tinggi lebih fleksibel untuk berbagai tujuan, termasuk kegiatan CSR, sumber daya ini lebih kaku dan hanya digunakan untuk tujuan tertentu. Darus et al. (2014) menyatakan bahwa di dalam institusi berlikuiditas tinggi seperti perusahaan keuangan, sumber daya tambahan berupa kelonggaran organisasi tidak digunakan untuk memulai kegiatan CSR, namun perusahaan lebih berfokus untuk menjaga likuiditas mereka seperti yang dipersyaratkan oleh industri. Hasil penelitian ini juga sejalan dengan penelitian Darus et al. (2014) dan Julia (2017) dimana slack resources tidak berpengaruh terhadap pengungkapan CSR.

\section{KESIMPULAN DAN SARAN}

Simpulan penelitian ini adalah variabel frekuensi rapat dewan komisaris dan sensitivitas industri berpengaruh secara positif signifikan terhadap pengungkapan CSR. Sedangkan, variabel diversitas gender dewan direksi dan kepemilikan manajerial berpengaruh secara negatif segnifikan terhadap pengungkapan CSR. Hipotesis yang ditolak atau tidak berpengaruh adalah pengaruh kepemilikan institusional dan slack resources terhadap pengungkapan CSR. Saran untuk penelitian selanjutnya yaitu menambah waktu penelitian serta menambah variabel independen lain seperti kompetensi dewan dan dualitas CEO. Penelitian kedepannya juga dapat menggunakan standar pengukuran GRI yang terbaru yakni GRI Standards yang diperkirakan dapat mempengaruhi pengungkapan CSR.

\section{DAFTAR PUSTAKA}

Anggraini, D. Y., \& Djakman, C. D. (2017). Slack resources, feminisme dewan, dan kualitas pengungkapan tanggung jawab sosial perusahaan (Jurnal Akuntansi Dan Keuangan Indonesia, 14(1), 94-118.

Barusman, Y. S., \& Lindrianasri. (2016). Determinant Of Corporate Social Responsibility: Case From Indonesia. Ekuitas: Jurnal Ekonomi Dan Keuangan, 20(80), 37-52. https://doi.org/1. http://dx.doi.org/10.24034/j25485024 .y2016.v20.i1.2036

Bourgeois, L. J. (1981). On the Measurement of Organizatonal Slack. Academy of Management Review, 6(1), 29-39.

Bouten, L., \& Everaert, P. (2015). Social and environmental reporting in Belgium: "Pour vivre heureux, vivons cachés." Critical Perspectives on Accounting, 33, 24-43. https://doi.org/10.1016/j.cpa.2014.10. 002

Charles, \& Chariri. (2012). Analisis Pengaruh Islamic Corporate Governance Terhadap Pengungkapan Corporate Social Responsibility (Studi kasus pada Bank Syariah di Asia). Diponegoro Journal of Management, 
1-15. Retrieved from http://ejournals1.undip.ac.id/index.php/accounting

Darus, F., Mad, S., \& Yusoff, H. (2014).

The Importance of Ownership Monitoring and Firm Resources on Corporate Social Responsibility (CSR) of Financial Institutions. Procedia - Social and Behavioral Sciences, 145, 173-180. https://doi.org/10.1016/j.sbspro.2014. 06.024

Diantimala, Y., \& Amril, T. A. (2018). The Effect of Ownership Structure , Financial and Environmental Performances on Environmental Disclosure, 7(1), 70-77. https://doi.org/10.15294/aaj.v5i3.200 19

Giannarakis, G. (2014). Corporate governance and financial characteristic effects on the extent of corporate social responsibility disclosure. Social Responsibility Journal, 10(4), 569-590. https://doi.org/10.1108/SRJ-02-20130008

Handrian, I., \& Fahmi, I. (2015). Pengungkapan Corporate Social Responsibility Berdasarkan Global Reporting Initiative 3.1 di Indonesia. Jurnal Aplikasi Manajemen (JAM), 13(1).

Haribowo, I. (2015). Analisis Pengaruh Islamic Corporate Governance Terhadap Corporate Social Responsibility (Studi Kasus Pada Bank Syariah di Indonesia). Jurnal Bisnis Dan Manajemen, 5(1), 147172.

Ibrahim, A. H., \& Hanefah, M. M. (2016). Board diversity and corporate social responsibility in Jordan. Journal of Financial Reporting and Accounting, 14(2), 279-298. https://doi.org/10.1108/JFRA-062015-0065

Machold, S., Ahmed, P. K., \& Farquhar, S. S. (2008). Corporate governance and ethics: A feminist perspective. Journal of Business Ethics, 81(3), 665-678. https://doi.org/10.1007/s10551-0079539-5

Naseem, M. A., Riaz, S., Rehman, R. U., Ikram, A., \& Malik, F. (2017). Impact Of Board Characteristics On Corporate Social Responsibility Disclosure. The Journal of Applied Business Reasearch, 33(4), 801-810.

Nugroho, M. N., \& Yulianto, A. (2015). Pengaruh Profitabilitas Dan Mekanisme Corporate Governance Terhadap Pengungkapan Csr Perusahaan Terdaftar Jii 2011-2013. Accounting Analysis Journal, 4(1), 112.

Purwanto, A. (2011). Pengaruh Tipe Industri, Ukuran Perusahaan, Profitabilitas, Terhadap Corporate Social Responsiblity. Jurnal Akuntansi \& Auditing, 8(1), 12-29. https://doi.org/10.14710/jaa.v8i1.434 4

Razak, R. A. (2015). Corporate Social Responsibility Disclosure and its Determinants in Saudi Arabia. MiddleEast Journal of Scientific Research, 23(10), 2388-2398. https://doi.org/10.5829/idosi.mejsr.20 15.23.10.22768

Rizki, L. A., Basri, H., \& Musnadi, S. (2014). Pengaruh Faktor Fundamental Dan Mekanisme Corporate Governance Terhadap Pengungkapan Corporate Social Responsibility Pada Perusahaan Manufaktur Yang Terdaftar di Bursa Efek Indonesia. Jurnal Magister Akuntansi Pascasarjana Universitas Syiah Kuala, 3(3), 35-45.

Robiah, A. M., \& Erawati, T. (2017). Pengaruh Leverage , Size, Dan Kepemilikan Manajemen Terhadap Corporate Social Responsibility Disclosure. Akuntansi Dewantara, 1(1), 39-48.

Sayekti, Y. (2017). The Effect of Slack Resources on Strategic Corporate Social Responsibility ( CSR ): Empirical Evidence on Indonesian Listed Companies. Global Journal of 
Business and Social Science Review, 5(2), 70-75.

Sembiring, E. R. (2005). Karakteristik Perusahaan dan Pengungkapan Tanggung Jawab Sosial: Studi Empiris pada Perusahaan yang Tercata di Bursa Efek Jakarta. Simposium Nasional Akuntansi XVI, (September), 379-395.

Solikhah, B. (2016). An Overview Of Legitimacy Theory On The Influence Of Company Size And Industry Sensitivity Towards Csr Disclosure, 14(5), 3013-3023.

Sunarsih, U., \& Nurhikmah. (2017). Determinant of The Corporate Social Responsibility Disclosure. Etikonomi, 16(2), 161-172. https://doi.org/10.15408/etk.v16i2.52 36

Susilawati, C. D. K., Tin, S., \& Agustina, L. (2014). Faktor-Faktor Fundamental Dan Jenis Industri Terhadap Corporate Social Responsibility Serta, 18(3), 384-395.

Undang-Undang Nomor 40 Tahun 2007 tentang Perseroan Terbatas. 2007. Jakarta: Presiden Republik Indonesia

Undang-Undang Nomor 25 Tahun 2007 tentang Penanaman Modal. 2007. Jakarta: Presiden Republik Indonesia

Undang-Undang Nomor 4 Tahun 2009 tentang Pertambangan Mineral dan Batubara. 2009. Jakarta: Presiden Republik Indonesia
Undang-Undang Nomor 19 Tahun 2003 tentang Badan Usaha Milik Negara. 2003. Jakarta: Presiden Republik Indonesia

Winarsih, A. M., \& Solikhah, B. (2015). Pengaruh Media, Sensitivitas Industri dan Struktur Corporate Governance Terhadap Kualitas Environmental Disclosure (Studi Pada Perusahaan High Profile di Bursa Efek Indonesia Periode 2011-2013). Accounting Analysis Journal, 4(2), 1-9.

www. kaltim.tribunnews.com. 2017. Aktivitas Tambang BDMS di Malinau Dihentikan. Diakses pada 28 Januari 2018, pukul 13.46. https://kaltim.tribunnews.com/2017/0 8/13/aktivitas-tambang-bdms-di malinau-dihentikan

www.riaunews.com. 2017. Ternyata PT EMA Tak Pernah Salurkan CSR. Diakses pada 29 Januari 2018, pukul 20.17 . https://riaunews.com/utama/ternyatapt-ema-tak-pernah-salurkan-csr/

Xu, E., Yang, H., Quan, J. M., \& Lu, Y. (2015). Organizational slack and corporate social performance: Empirical evidence from China's public firms. Asia Pacific Journal of Management, 32(1), 181-198. https://doi.org/10.1007/s10490-0149401-0 